\title{
God in Translation. Deities in Cross-Cultural Discourse in the Biblical World
}

\author{
Smith, MS \\ Grand Rapids: Eerdmans \\ 2010 \\ $382 \mathrm{pp}, \$ 40.00$ \\ Reviewed by HL Bosman \\ Old and New Testament \\ Stellenbosch University
}

ark S Smith is the Skirball Professor of Bible and Ancient Near Eastern Studies at New York University and has received scholarly acclaim for previous books on the religion of ancient Israel, such as The Early History of God: Yahweh and Other Deities in Ancient Israel.

In this monograph Smith "undertakes an exploration of intercultural contact over three major periods in ...the 'biblical world' (both Hebrew Bible and New Testament)" (p. ix):

- The ancient Near East during the Late Bronze Age (Chapter 1)

- Ancient Israel during the monarchy and Post-Exile (Chapters 2-4)

- Hebrew Bible and New Testament during the Greco-Roman times (Chapters 5-6)

The golden thread running through the book is the 'translatability' of deities, namely how deities of various cultures were identified or recognized by name across cultural boundaries (p. x). In similar vein 'translatability' is described as a phenomenon that "involves specific equations or identifications of deities across cultures and the larger recognition of deities of other cultures in connection with one's own deities" (p. 6). This 'translatability' often functioned in antiquity as a conduit for imperial power and Smith pays special attention to the impact of the Mesopotamian Empires on divinity in Israel.

There is also a clear polemical edge to Smith's research when ancient record is reconstructed to disprove modern claims that "traditional forms of monotheism, for example in Judaism and Christianity", lead to intolerance and violence. Jan Assmann, well known Egyptologist from Heidelberg University, is taken to task because of his book on Moses the Egyptian: The memory of Egypt in Western Monotheism (1997) in which he postulated a 'Mosaic distinction' in ancient Israel that presumed that ancient Israel resisted translating the gods of other cultures as bona fide deities. According to Smith the ancient records do not substantiate such a claim because monotheism in several instances resisted imperial power and maintained 'local cultural traditions' (p. x).

This monograph must be evaluated against the following presuppositions (pp. 15-16):

a) The translatability of deities is discussed in a representative sample of texts and not in 'an exhaustive catalogue' that is intended 'to be a comprehensive compilation of possible examples.' 
b) The possible implications of art and archaeological sources (especially iconography) for translatability are only occasionally discussed and there is a laudable recognition of complexities involved in the interpretation of artistic representations of divine beings: how can a distinction be made between culturally influenced artistic style and personal preference?

c) Restraint is exercised not to place too much emphasis on examples where texts were clearly adapted across cultures (i.e. The Egyptian Words of Amenemope and Proverbs 22:17-23:11). The emphasis in this study falls on 'cross cultural recognition of deities themselves.'

d) Although the concept of 'translatability' is closely related to the more often used 'monotheism' and 'polytheism,' it allows for a more comprehensive understanding of the historical development of religion in ancient Israel and early Christianity.

Mark Smith has succeeded in drawing together information from ancient Near Eastern and biblical resources, as well as combining perspectives gleaned from theology, history of religion and comparative religion. In a time when academic research is characterized by increasing specialisation, this multidisciplinary approach must be applauded. The multidisciplinary approach is also reflected in the Index of Sources where one can trace what ancient Near Eastern, early Jewish and classical Christian texts were incorporated in the cross cultural discussion of deities in the biblical world.

A person considering reading this monograph should take note of the concluding two sentences (p. 340):

Translatability of divinity is no mere academic task; it is a central task of human selfunderstanding. Otherwise, in this situation, something of our humanity - and arguably of our divinity - may be lost.

To conclude with a few more critical remarks:

- 'Translatability' remains a slippery term more often used in cultural studies and social anthropology and the jury is still out whether it facilitates the breaking of new ground in the cross - cultural discussion of deities in the ancient Near East. One could ask what was gained and what was lost in the use of 'translatability'?

- The historical reliability of the biblical text seems to be accepted more often than not. A more cautious approach to such matters seems to be prudent and will add to the value of a monograph that deserves careful scrutiny.

- A final more trivial comment: the Subject Index does not do justice to the variety of topics addressed in the monograph and is primarily a list of proper names. 